\title{
Morphological and molecular characterisation of the Popijač's Yellow Sally, Isoperla popijaci sp. nov., a new stenoendemic stonefly species from Croatia (Plecoptera, Perlodidae)
}

\author{
Dora Hlebec', Ignac Sivec², Martina Podnar³, Josip Skejo', Mladen Kučinićl \\ I Department of Biology, Faculty of Science, University of Zagreb, Rooseveltov trg 6, 10000 Zagreb, Croatia \\ 2 Slovenian Museum of Natural History, Prešernova 20, 1000 Ljubljana, Slovenia 3 Croatian Natural History \\ Museum, Demetrova 1, 10000 Zagreb, Croatia \\ Corresponding author: Dora Hlebec (dora.hlebec@biol.pmf.hr)
}

Academic editor: Sven Bradler | Received 25 March 2021 | Accepted 31 October 2021 | Published 16 December 2021

http://zoobank.org/359F5F54-1DFA-4A78-8F7B-D8B042F40E1E

Citation: Hlebec D, Sivec I, Podnar M, Skejo J, Kučinić M (2021) Morphological and molecular characterisation of the Popijačs Yellow Sally, Isoperla popijaci sp. nov., a new stenoendemic stonefly species from Croatia (Plecoptera, Perlodidae). ZooKeys 1078: 85-106. https://doi.org/10.3897/zookeys.1078.66382

\begin{abstract}
A new species of the Yellow Sally genus (Isoperla Banks, 1906) is described, based on morphological (males and females adults, larval and egg) and molecular (the barcode region of the cytochrome coxidase subunit I gene (COI)) features. Popijačs Yellow Sally, I. popijaci Hlebec \& Sivec, sp. nov. inhabits two karstic sources of the Krasulja rivulet in Croatia. Male and female of the new species are characterised by colouration patterns of the head and pronotum; the dimensions of the female subgenital plate; the medial penial armature and oval-shaped egg without collar and anchor. The larvae differ from their congeners by the uniquely coloured head and pronotum. Based on morphological characteristics I. popijaci sp. nov. belongs to the I. tripartita species group. Phylogenetic and taxonomic relationships were reconstructed using three methods of phylogenetic inference and three species delimitation methods. As I. popijaci sp. nov. occurs at a narrow area of the Krasulja rivulet in Krbava field, the study puts emphasis on the conservation and hotspot importance of the temporary rivers in the Dinaric karst. Furthermore, the study accentuates the necessity for further research on the genetic diversity of Plecoptera in Croatia.
\end{abstract}

\section{Keywords}

Conservation, Dinaric karst, DNA barcoding, Isoperla popijaci sp. nov., karstic source, species delimitation

Copyright Dora Hlebec et al. This is an open access article distributed under the terms of the Creative Commons Attribution License (CC BY 4.0), which permits unrestricted use, distribution, and reproduction in any medium, provided the original author and source are credited. 


\section{Introduction}

Predominantly regarded as a biological indicator of well oxygenated water in freshwater ecosystems (Illies and Schmitz 1980; Hamid and Rawi 2017; Morinière et al. 2017; DeWalt and Ower 2019; Ferreira et al. 2020), stoneflies (Plecoptera) and their absence can indicate pollution, changes in habitat conditions, habitat destruction and climate changes (Urbanič and Toman 2007; Fochetti and Tierno de Figueroa 2008; Bálint et al. 2011). In total, 50 Plecoptera species are reported from Croatia and, due to the many suitable habitats, it is assumed that this number is higher (Popijač and Sivec 2009a, 2009b). Members of the subfamily Perlodinae are, in general, vividly coloured, medium to large-sized, show high genetic diversity and are often microendemic (Zwick 1973, 2004; Li and Murányi 2015). The genus Isoperla Banks, 1906 is represented by 188 species worldwide and 60 species in Europe (DeWalt et al. 2020). The genus has a Holarctic and Oriental distribution (Zwick 1973; Szczytko and Stewart 1979; Sandberg and Kondratieff 2013; Szczytko and Kondratieff 2015) and represents the most diverse genus of the family Perlodidae in Europe (Graf et al. 2009, 2018). Thereby, the area of the Balkan stands out as a diversity hotspot with 21 species, of which 12 are endemic to the Peninsula and often restricted to specific habitats (Murányi 2011; Murányi et al. 2016).

Basic characteristics by which the species within the genus Isoperla are distinguished are penial morphology, head and pronotal pattern, egg structures and drumming signals (Despax 1936; Illies 1952, 1954, 1966; Sivec and Stark 2002; Murányi 2011; Michalik et al. 2017). In the last few years, a considerable number of new Plecoptera taxa have been described, especially from China ( $\mathrm{Li}$ et al. 2013; Ji et al. 2014; Li and Murányi 2015; Chen et al. 2019; Cao et al. 2020), but also in Europe, like Isoperla pesici Murányi, 2011; I. autumnalis Murányi, 2011; I. citrina Murányi, 2011 (Murányi 2011; Murányi et al. 2016); I. vjosae Graf et Vitecek, 2018 (Graf et al. 2018); I. claudiae Graf et Konar, 2014 (Graf et al. 2014) and I. nagyi Murányi, Kovács et Graf, 2020 (Murányi et al. 2020).

During fieldwork research since 2004, ten Isoperla species were recorded in Croatia. An additional one is here described as Isoperla popijaci sp. nov., which shares morphological characteristics of the penial armature with species from the I. tripartita species group.

The following study provides a morphological description of the new species: illustrations of the main taxonomical characters (in males, females, larvae and eggs); as well as its phylogenetic placement within the genus based on the mitochondrial cytochrome coxidase subunit I (COI) barcode region as a marker. Moreover, the conservation importance of the intermittent Krasulja rivulet and its watercourse, as well as Dinaric karst (Western Balkan region) is discussed.

\section{Materials and methods}

Material collection and preparation.

Adults of $I$. popijaci sp. nov. were collected in June 2019 at the entrance to the Ševerova Cave (karstic source of the intermittent Krasulja rivulet in Krbava field). 
A subsequent collecting trip upstream of the Krasulja rivulet (in June 2021), near the karstic source adjacent to the village of Mirići, resulted in finding more specimens of I. popijaci sp. nov.

A total of 42 specimens (34 adults and 8 larvae) belonging to Isoperla popijaci sp. nov., were collected. Adult specimens were collected using sweep nets, while larval specimens were collected by handpicking. The aedeagus was everted in the field and specimens were fixed and stored in $96 \%$ ethanol for morphological and molecular analysis. Morphological characteristics of male terminalia were examined after potassium hydroxide $(\mathrm{KOH})$ treatment.

\section{Type material depository and museum acronyms.}

The holotype and part of the paratypes series are deposited in the Croatian Natural History Museum, Zagreb, Croatia (CNHM), Collection of Plecoptera Sivec \& Hlebec, while other paratypes are kept in the Slovenian Museum of Natural History, Ljubljana, Slovenia (PMSL).

\section{Photography and drawings.}

Photographs, diagnostic characterisation and comparative morphological examination of specimens were made using a ZEISS SteREO DiscoveryV.20 stereomicroscope. Pencil drawings were produced with a camera lucida and then digitally edited and inked. Figures 3A, B, 4A-D (SEM images) were made using a JEOL JSM-7000F scanning electron microscope. The penis (one of paratype specimen) for the SEM study was critical-point dried (Figure 4A-D).

Nomenclature is in accordance with the International Code of the Zoological Nomenclature (ICZN 1999). The species is proposed by following the rules of the Code. Abbreviations for the type specimens are HT-holotype, PT-paratype and PTs-paratypes.

\section{Comparative analysis.}

Comparative study on the morphology of penial structures was conducted using ten species belonging to the genus Isoperla, collected in Croatia: I. bosnica Aubert, 1964; I. inermis Kaćanski et Zwick, 1970; I. rivulorum (Pictet, 1841); I. lugens (Klapálek, 1923); I. illyrica Tabacaru, 1971; I. tripartita Illies, 1954; I. grammatica (Poda, 1761); I. difformis (Klapálek, 1909); I. oxylepis (Despax, 1936) and I. albanica Aubert, 1964. Morphological taxonomic classifications follow the traditional system (Poda 1761; Pictet 1841; Klapálek 1909, 1923; Despax 1936; Illies 1952, 1954, 1966; Aubert 1964; Tabacaru 1971; Kaćanski and Zwick 1970, Murányi 2011; Murányi et al. 2016).

\section{DNA extraction, amplification, and sequencing.}

One male, one female and one larva of Isoperla popijaci sp. nov. were used in molecular analyses and mutually associated. DNA was extracted from the single leg 
of specimens using QIAamp DNA Micro Kit (Qiagen, Germany) according to the manufacturer's specifications and eluted in $50 \mu \mathrm{l}$ of elution buffer. The 5' fragment of the mitochondrial cytochrome c oxidase subunit I gene (COI) was amplified using standard PCR-protocols and four sets of primers: LCO-1490/HCO-2198 (Folmer et al. 1994) or C_LepFolF/C_LepFolR (as was used in Hebert et al. 2004) or a combination of MLepF1/LepR1 and MLepR1/LepF1 (yielding two shorter, overlapping fragments as was used in Hajibabaei et al. 2006) in $20 \mu \mathrm{l}$ reactions. Polymerase chain reactions (PCRs) for all primer sets were carried out using: $1 \times$ DreamTaq reaction buffer with $2 \mathrm{mM} \mathrm{MgCl}$ (Thermo Fisher Scientific Inc., US), $0.2 \mathrm{mM}$ dNTPs, 0.4 $\mu \mathrm{M}$ of each primer, $0.025 \mathrm{U} / \mu \mathrm{l}$ of DreamTaq polymerase (Thermo Fisher Scientific Inc., US) and $1 \mu \mathrm{l}$ of eluted DNA. For the first mentioned primers set (LCO-1490/ HCO-2198) the following PCR cycling conditions were applied: initial denaturation at $95^{\circ} \mathrm{C}$ for $2 \mathrm{~min}$, followed by 35 cycles of denaturation at $95^{\circ} \mathrm{C}$ for $30 \mathrm{~s}$, annealing at $50^{\circ} \mathrm{C}$ for $30 \mathrm{~s}$, extension at $72^{\circ} \mathrm{C}$ for $1 \mathrm{~min}$, followed by a final extension step at $72^{\circ} \mathrm{C}$ for $10 \mathrm{~min}$. PCR products were purified using Exonuclease I $(0.05 \mathrm{U} /$ $\mu \mathrm{l})$, FastAP Thermosensitive Alkaline Phosphatase $(0.025 \mathrm{U} / \mu \mathrm{l})$ enzymatic system (Thermo Fisher Scientific Inc., US). The reaction was carried using the protocol: $1 \mathrm{~h}$ at $37^{\circ} \mathrm{C}$ followed by $20 \mathrm{~min}$ at $80^{\circ} \mathrm{C}$. Sequencing was performed by Macrogen Inc. (Amsterdam, The Netherlands) using the amplification primers. Sequences obtained in the study were deposited in the BOLD database (Ratnasingham and Hebert 2007) and GenBank (under the accession numbers MW907977-MW907980, MW907982-MW907988 and MW907990-MW907993).

\section{Sequence data and phylogenetic analysis.}

In total, 15 obtained Isoperla sequences were checked, edited, assembled from both directions and inspected manually for base-pair ambiguities, as well as stop codons, indels or double peaks in chromatograms (as indicators for the possible erroneous amplification of nuclear mitochondrial pseudogene) in Geneious R6 (https://www. geneious.com). All available Isoperla sequences were retrieved from the GenBank and BOLD databases (accessed 10/01/2021) and aligned with sequences from this study using MAFFT v.7 (Katoh and Standley 2013). Any length variants were excluded from the final alignments. Sequences were collapsed into 456 unique COI haplotypes using the online tool FaBox v.1.5 (Villesen 2007) and, from all species, the most diverse haplotypes from I. tripartita and I. rivulorum species group, as well as species $I$. lugens, were retained for further analysis. The final dataset for phylogenetic analysis and species delineation comprised 27 sequences, including 10 haplotypes observed in this study (see Table 1). Isoperla obscura (INTAP055-17) and Taeniopteryx burksi (08INHSP-002) were selected as outgroups according to the North American Plecoptera phylogeny published by South et al. (2020). Amongst morphologically-defined species, evolutionary divergence was estimated using the pairwise comparison of the uncorrected genetic distances ( $p$-distances) in MEGA-X (Kumar et al. 2018). For $p$ distances, a colour heat map was drawn using the Python data visualisation library Seaborn (version 0.11.1, Waskom 2021). Phylogenetic relationships were estimated 


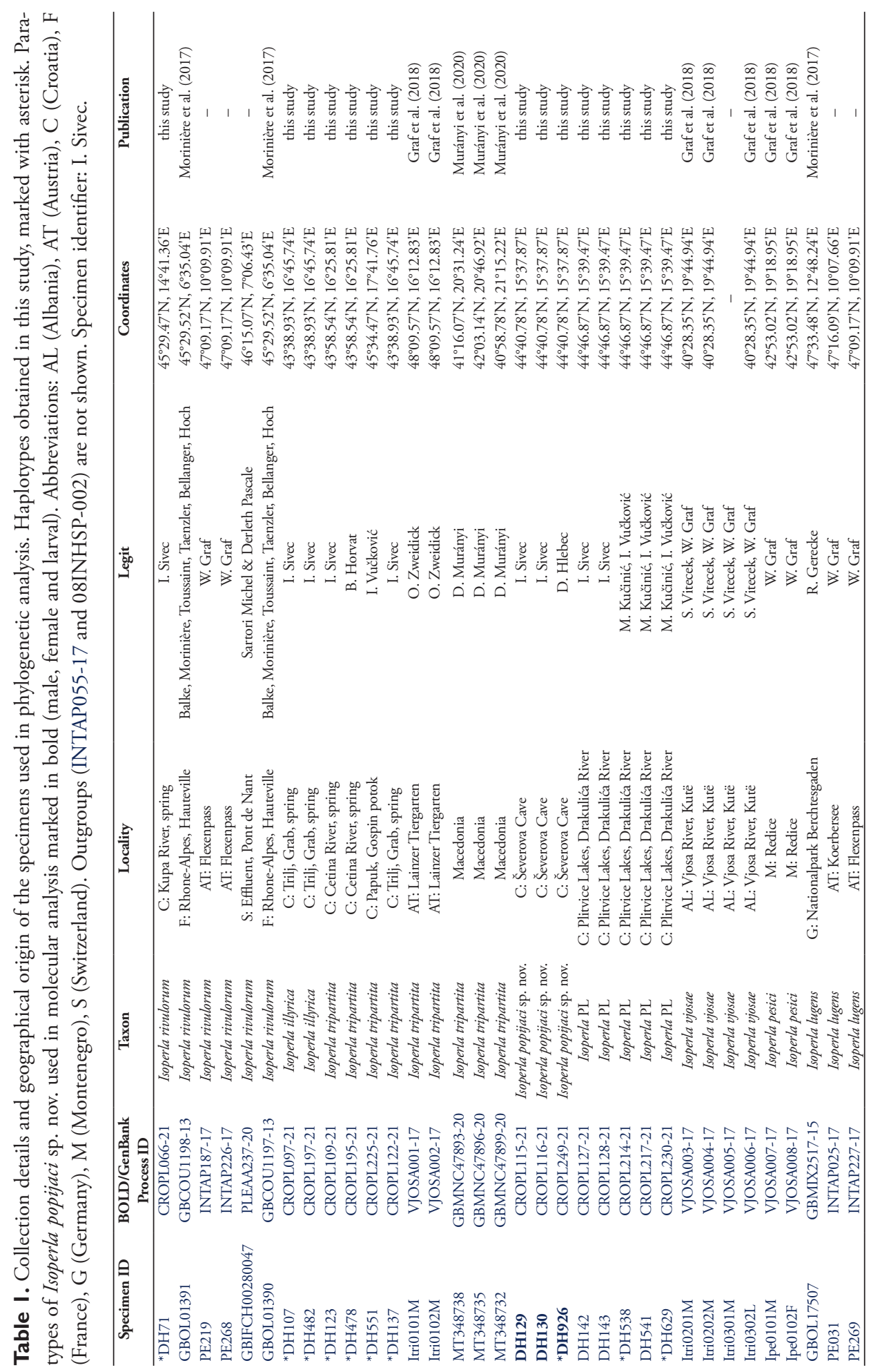


by three different optimality criteria: Neighbour Joining (NJ), Maximum Likelihood (ML) and Bayesian Inference (BI). NJ and ML were performed in MEGA-X (Kumar et al. 2018), while BI in MrBayes 3.2.7. (Ronquist et al. 2012). For ML and BI, the optimal model of nucleotide evolution (Hasegawa-Kishino-Yano model with gamma distributed rate variation amongst sites and a significant proportion of invariable sites: $\mathrm{HKY}+\mathrm{I}+\mathrm{G}$ ) was selected under the Bayesian Information Criterion (BIC) using jModelTest 2.1.5 (Darriba et al. 2012). Nodes in the phylogenetic trees with bootstrap values $\mathrm{P} \geq 70$ in $\mathrm{NJ}$ and $\mathrm{ML}$ and posterior probabilities values $\mathrm{pp} \geq 0.90$ in $\mathrm{BI}$ were considered well supported. NJ was made using the Kimura-2-parameter (K2P) model of nucleotide substitution with the pairwise deletion option. Bootstrap support was inferred using the fast bootstrap algorithm, based on 5000 replicates. Nearest-Neighbour-Interchange (NNI), a heuristic method using the fast bootstrap algorithm, was used in ML with 1000 replicates.

For BI, the dataset was partitioned by codon positions. Two separate runs with four Metropolis-coupled Monte Carlo Markov chains (MMCM) were performed for 10 million generations while trees were sampled every 1000 generations with the first $25 \%$ of sampled trees discarded as burn-in. The remaining trees were used to create a 50\% majority rule consensus tree. TRACER v.1.7.1 (Rambaut et al. 2018) was used to check the convergence between the two runs. The phylogenetic trees were visualised using FigTree v.1.4.3. (Rambaut 2009) and iTOL v.5 (Letunic and Bork 2021). Several methods of species delimitation were applied: the Automatic Barcode Gap Discovery (ABGD) method (Puillandre et al. 2012), the Bayesian implementation of the Poisson Tree Processes (bPTP) method (Zhang et al. 2013) and the multi-rate Poisson Tree Process (mPTP) method (Kapli et al. 2017). The ABGD was performed at the web server by using the K2P model. All values were set to default, except the value of relative gap width, which was set to 1 , while the default gap width of 1.5 resulted in a single group. The bPTP method was performed on the web server at http://species.hits.org, while the mPTP method was run on the web server at http://mptp.h-its.org/. Both methods were applied using default parameters, outgroups have been removed from the analysis and the same ML input tree was used.

\section{Results}

Taxonomic part

\section{New species description}

Isoperla popijaci Hlebec \& Sivec sp. nov.

http://zoobank.org/60B76C3E-14C2-4D5D-9587-C1931C87952B

Figures 1A-E, 2A-G, 3A, B, 4A-D

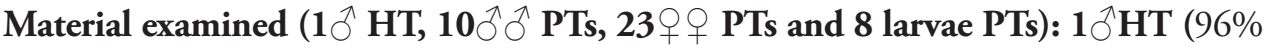
ethanol) Original label: Croatia, Lika, Krbava field, Krasulja rivulet, karstic source Ševerova Cave; $44^{\circ} 40.78^{\prime} \mathrm{N}, 15^{\circ} 37.87^{\prime} E, 21$ June 2019, I. Sivec leg. (CNHM: CPSH); 
$6 \hat{0} 0^{1}$ PTs and 11 + $q$ PTs (96\% ethanol) same data as for the holotype; 5 larvae PTs (96\% ethanol) 09 April 2015, I. Sivec leg.; 3 larvae PTs (96\% ethanol) 22 February 2021, D. Hlebec leg.; $1 \overbrace{}^{\lambda} \mathbf{P T}$ and $3 \circ q$ PTs (96\% ethanol) 2 June 2021, I. Sivec leg.; $3 \circ q$ PTs

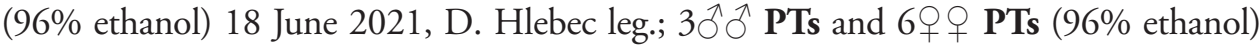
karstic source nearby village Mirići, $44^{\circ} 43.14^{\prime} \mathrm{N}, 15^{\circ} 38.09^{\prime} \mathrm{E}, 2$ June 2021, I. Sivec leg.

Type material depository. $\mathrm{HT}(1 \hat{\jmath})$ and $31 \mathrm{PTs}(7 \hat{\jmath} \hat{\partial}+18+q+6$ larvae) in Zagreb, Croatia (CNHM), Collection of Plecoptera Sivec $\&$ Hlebec, under accession number CPSH 1-32; and 10 PTs $(3 \widehat{\jmath}+5$ 우 +2 larvae) in Ljubljana, Slovenia (PMSL).

Type locality. Croatia, Lika, Krbava field, Krasulja rivulet, karstic source Ševerova Cave, $44^{\circ} 40.78^{\prime} \mathrm{N} ; 15^{\circ} 37.87^{\prime} \mathrm{E} ; 640 \mathrm{~m}$ a.s.l.

Diagnosis. The new species I. popijaci sp. nov. belongs to the I. tripartita species group, with divided medial penial armature into upper and lower coloured portions. It has, however, a specific penial armature on the ventral lobe of the penis, different from all known Isoperla species. The upper medial armature is subdivided, and the lower medial armature is present in two scale spike-like areas. The proximal part has a pair of drop-shaped areas armoured with spines, longer at the tip and shorter at the base. The medial penial armature with a field of shorter spines as in Figure 4C. Only a few irregular spines on the lateral side of the penis in the area of the upper armature of the penis.

Description. Macropterous in both sexes, medium-sized species with yellow head and pronotum.

ADult. Body length: HT male $18.5 \mathrm{~mm}$; PTs: males $17-19 \mathrm{~mm}(\mathrm{n}=10)$, females $16.5-18 \mathrm{~mm}(\mathrm{n}=23)$.

Forewing length: HT male $12 \mathrm{~mm}$; PTs: males $11-13.5 \mathrm{~mm}$, females $11.5-14 \mathrm{~mm}$.

Colouration. General colour uniformly brownish (Figure 1C), slightly paler ventrally and laterally.

Head. The central part of the head pale yellowish; darker at the lower part and between ocelli; slightly darker in the frontal and lateral part. M-line and tentorial callosities weakly expressed and inconspicuous. Pale spot positioned centrally between the ocelli, paler in the central distal part of the head. Eyes slightly smaller than the area delimited by the three ocelli. Scape and pedicel dark brown. Palpi uniformly cream coloured. The distal part of the antennae pale and the proximal segments darker (Figures 1A, 2A).

Wings. Wings translucent brownish, venation dark brown.

Pronotum. Pronotum yellowish, rectangular with angled edges. Medial and lateral parts of the pronotum pale; central part on both sides slightly darker and with dark brown textured surface (Figures 1A, 2A).

Mesothorax and metathorax. Ventral surface of thorax uniformly brownish; dorsal side slightly darker, lateral part lighter. Mesonotum and metanotum predominantly dark brown.

Legs. Femora and tibia brownish, same as body colouration. Tarsi slightly darker than femora and tibia on the dorsal side and pale ventrally.

Male abdomen. Mesobasisternum and metabasisternum brown in the middle and darker laterally. Ventral surface of male abdomen uniformly brownish, slightly darker dorsally. A few proximal segments of cerci pale, with rest dark brown. 

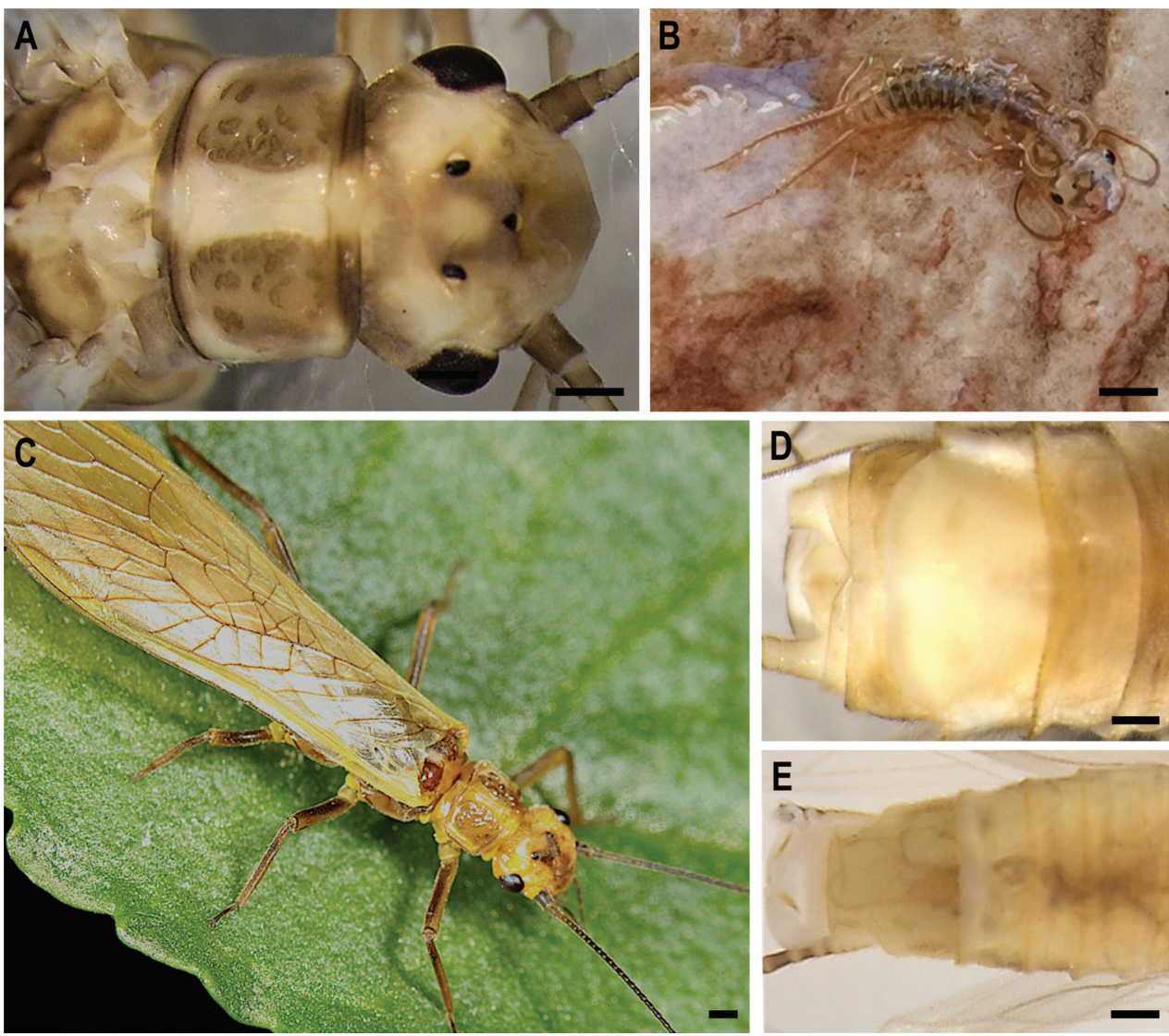

Figure I. Morphology of Isoperla popijaci sp. nov. A head and pronotum in dorsal view (adult male HT) $\mathbf{B}$ habitus (larval PT) $\mathbf{C}$ habitus (adult male PT) D female terminalia in ventral view (PT) E everted male copulatory organ (HT). Scale bar: $0.5 \mathrm{~mm}$ A-E.

Penis (everted). Divided into four lobes, with a basal section in everted position. The medial penial armature on the ventral surface of the penis divided into an upper and a lower part, both are coloured (Figures 2C, G, 4A), upper part rather pale. The upper medial penial armature is further subdivided into left and right arms, elongated, delimited from scales of the lateral lobes (Figure 4C). Length of the arms is $200-250 \mu \mathrm{m}$, width 100-120 $\mu \mathrm{m}$. Scales of the upper medial penial armature forming a drop-shaped area, spike-like, with longer scales at the tip and shorter ones at the base. Length of the scales 25-37 $\mu \mathrm{m}$, width 7-9 $\mu \mathrm{m}$ at the base. The lower part of the medial penial armature subdivided, with an irregular upturned V-shaped area and bearing very short spines (Figure 4D). Length of the areas $220-250 \mu \mathrm{m}$, width $100-140 \mu \mathrm{m}$. The scales are spikelike, thinner than in the upper medial armature. The ventral lobe hemispherical, covered with hair-like scales, in some places ciliated scales. The medial lobe small with diverse scales. Lateral penial armatures located on the lateral lobes, above the basal section, small and indistinct with only a few spines. Detail of the lateral lobe as in Figure 4B. 

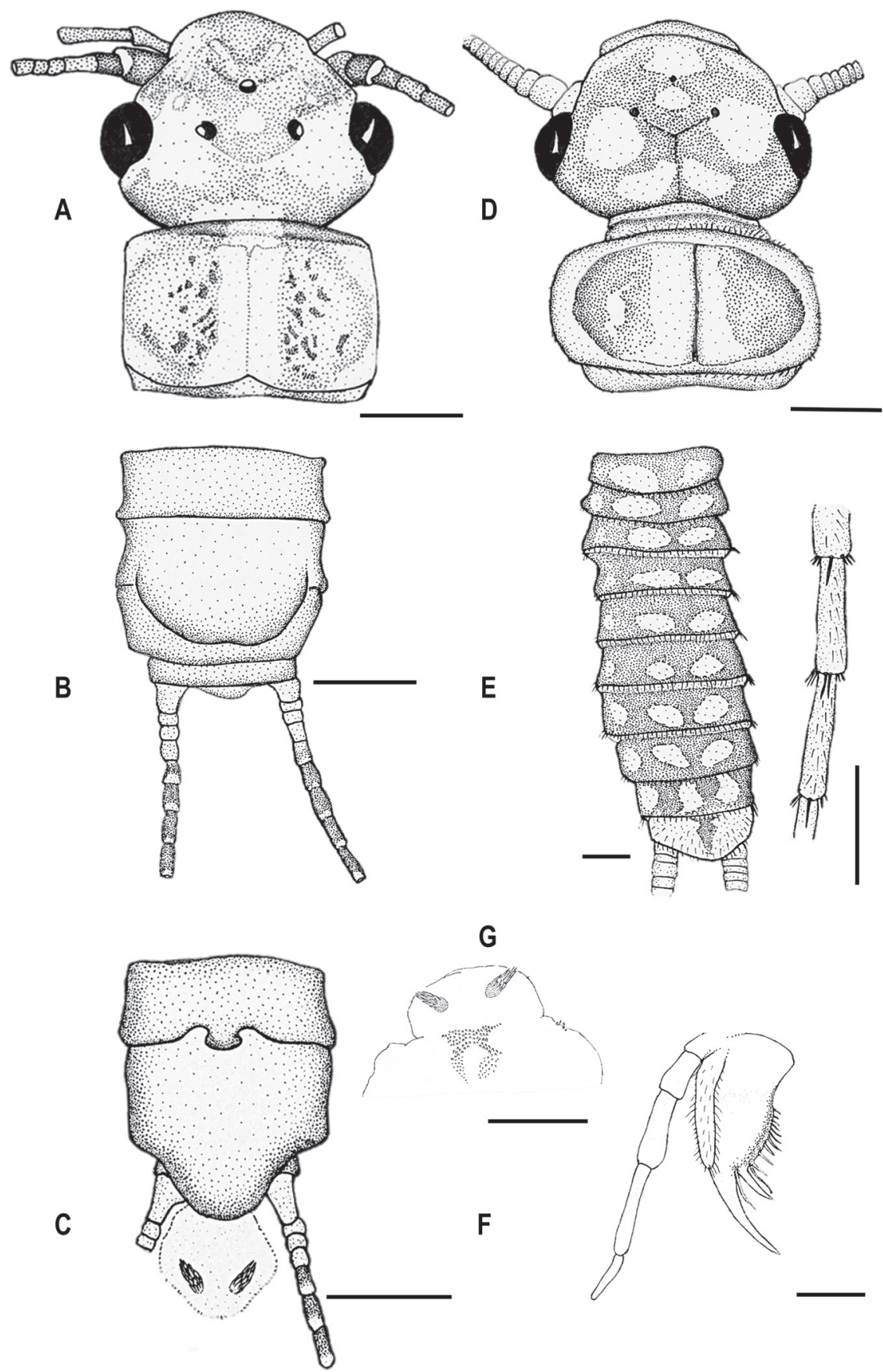

Figure 2. Morphology of Isoperla popijaci sp. nov. A head and pronotum in dorsal view (adult female PT) B terminalia in ventral view (adult female PT) $\mathbf{C}$ terminalia in ventral view (adult male HT) D head and pronotum in dorsal view (larval PT) E abdomen in dorsal view and detail of a distal segment of a cercus (larval PT) F right maxilla in dorsal view (larval PT) G penial armature (adult male HT). Scale bars: $1 \mathrm{~mm}(\mathbf{A}-\mathbf{D}) ; 0.5 \mathrm{~mm}(\mathbf{E}-\mathbf{G})$. 

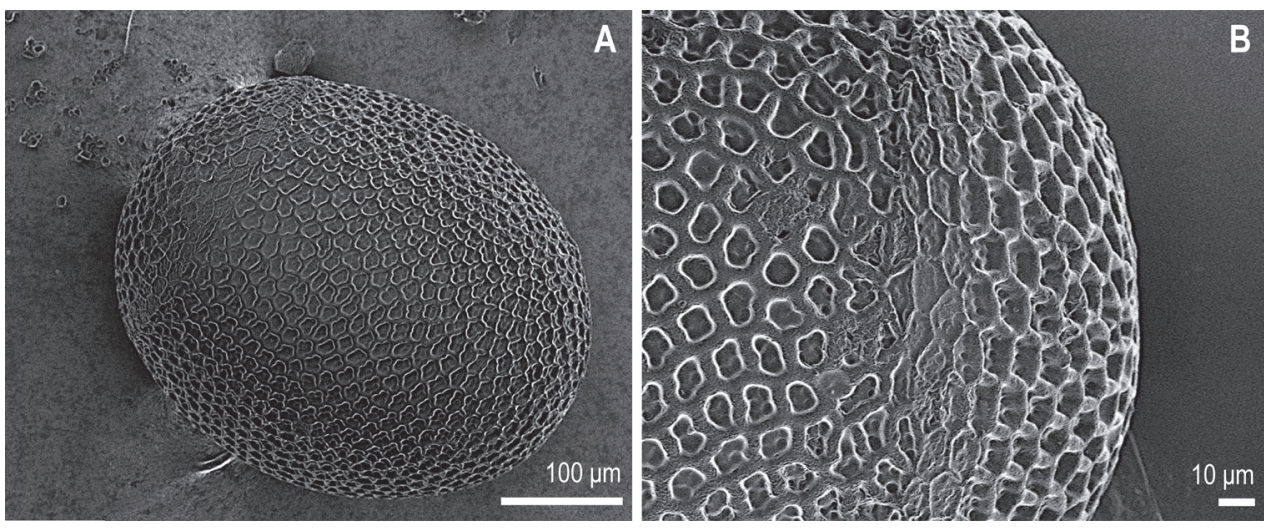

Figure 3. Egg of Isoperla popijaci sp.nov. A whole egg, lateral view B detail of hatching line, lateral view

Female abdomen. All tergites uniformly brownish. Sternites slightly paler brownish. A few basal segments of cerci pale, rest of cerci dark brown. Subgenital plate large and wide reaching near the end of sternite IX (widely concave in the middle) (Figure 2B).

Egg. Chorion light brown, 0.34-0.38 $\mathrm{mm}$ long and $0.29-0.33 \mathrm{~mm}$ wide ( $\mathrm{n}=22$ ). Chorion with marked ornamentation of irregular round shape. Follicular cell impressions with finer inner punctations. Hatching line distinct. Micropyles not well recognisable. Collar and anchor missing (Figure 3A, B).

Larva. Body length of not-completely-mature larva 14-16 mm (n=8). General colour pale brownish; with darker markings on head and abdomen. Body and legs typically pilose. Swimming hairs present on femora, tibiae and tarsi. Posterior abdominal fringe short and cercal fringe no longer than width of cercal segment. General colour of the head brownish, with a darker transversal mask connecting eyes and ocelli (Figure 2D). M line indistinct. Eyes well developed. Mouth parts and basal parts of antennae pale coloured; distal part of antennae dark brownish. Lacinia bidentate; inner margin with 4-5 stout setae and a row of short thin setae below subapical tooth. Pronotum rounded; brownish; with indistinct darker pattern centrally and distinctly paler laterally (Figure 2D). Pronotal setal fringe with short bristles and bearing only a few longer setae at posterior margin. Ventral side of the body and leg pale coloured. Abdominal tergites darker, brown with a pair of relatively large dropshaped pale spots in the middle of the abdomen (Figure 2E). Paraprocts and cerci uniformly pale. Setation on distal section of cercal segments with rather uniform setae and single larger dorsal setae.

Etymology. The specific name is the genitive singular of the Latinised version of the surname Popijač (Popiacus, -i, m.), given in honour of colleague Dr Aleksandar Popijač and his achievements in field research and knowledge of the Plecoptera fauna in Croatia.

Distribution and ecology. The species was collected at the entrance to the Ševerova Cave, occasional karstic source of the intermittent Krasulja rivulet in Krbava field and two year later (on 2 June 2021) near the karstic source of the same rivulet, 

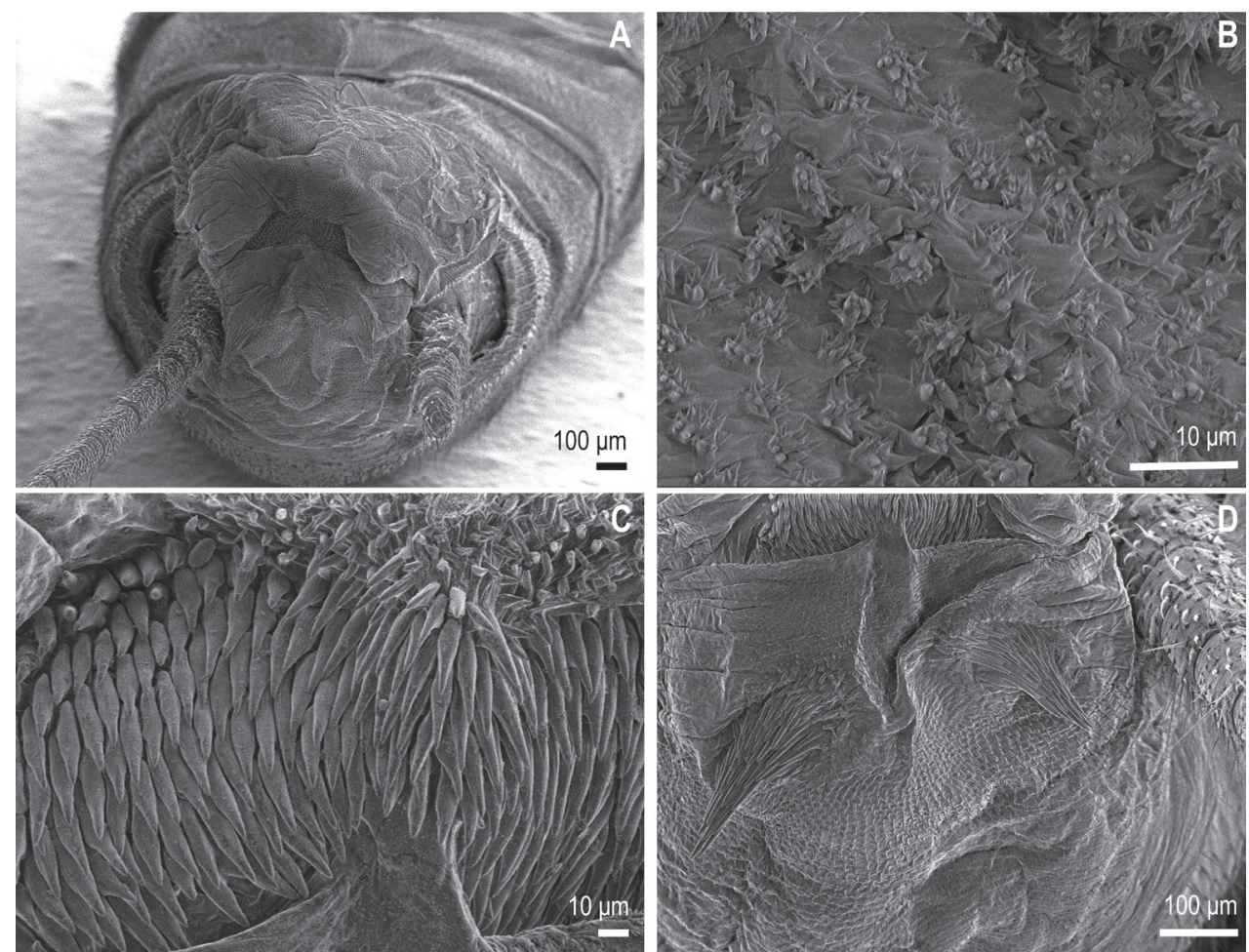

Figure 4. Extruded penis of Isoperla popijaci sp. nov. A male abdomen with extruded penis, ventral view B detail of penial armature on the lateral lobe, dorsal view $\mathbf{C}$ scales of the upper medial penial armature, dorsal view $\mathbf{D}$ pair of the scales spike-like on the ventral lobe, dorsal view.

near the village of Mirići. The Ševerova Cave (old name Hrnjakova Cave) is located on the northern edge of the Krbava field (karst field located near settlement Krbavica in the vicinity of the Plitvice Lakes National Park). The temporary Krasulja rivulet is part of the hydrogeological system of the Krbavica River (Figure 5E). For several months a year, the water runs from the cave and forms the Krasulja rivulet, which flows into the Krbavica River and sinks on the south side of the field. When the discharge of the Krasulja falls below 60 1/sec, the water-flow ceases from Ševerova Cave (Malinar and Čepelak 2009). The stream does not have a rich stonefly fauna and the species found at this locality, except the newly-described species of Isoperla, are Amphinemura standfussi (Ris, 1902) and Nemoura cinerea (Retzius, 1783). The substrate at the collection site of larvae was mainly composed of larger fractions.

\section{Conservation status}

The new species should probably be regarded as Critically Endangered (CR) or Vulnerable (VU) by the IUCN Criteria. Up to now, it is known only from the areas nearby two karstic sources. 


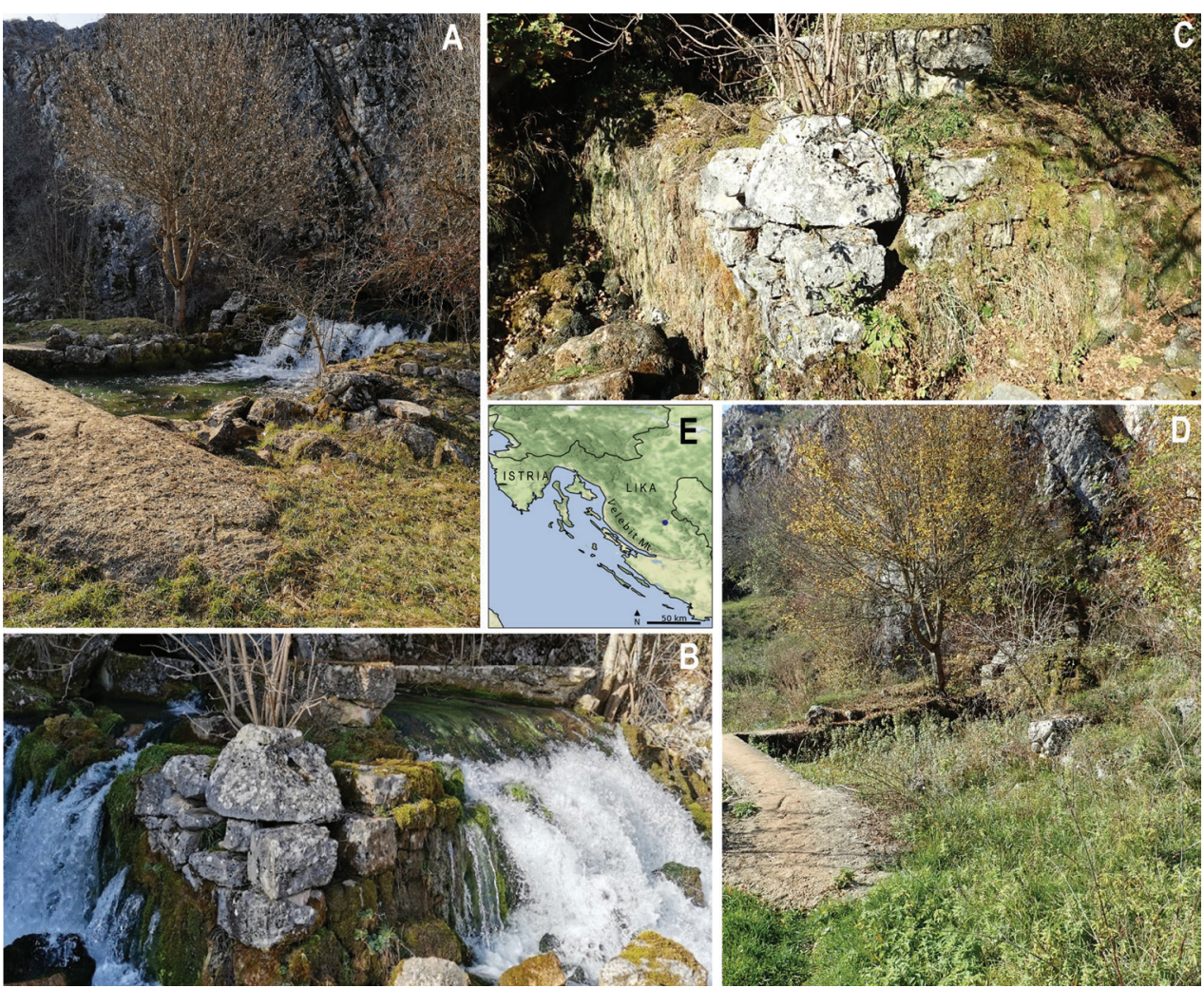

Figure 5. Type locality of the Popijačs Yellow Sally, Isoperla popijaci sp. nov.: Ševerova Cave in Croatia A and $\mathbf{B}$ photographs in wet phase $\mathbf{C}, \mathbf{D}$ photographs in dry phase $\mathbf{E}$ map (blue circle indicates type locality).

\section{Phylogenetic part}

The alignment of COI gene sequences was $658 \mathrm{bp}$ in length and comprised of 202 variable sites, of which 139 were parsimony informative. Three implemented criteria of phylogenetic reconstruction (NJ, ML and BI) resulted in congruent topologies with highly similar support values (Figure 6), characterised by the presence of two deeply divergent lineages, I. popijaci sp. nov. and "Isoperla PL", which did not cluster with any of the currently defined taxa.

Mitochondrial COI sequences, obtained from I. popijacisp. nov. (adults and larva), were identical (a single unique haplotype). The monophyly of the newly-described species is highly supported (Figure 6). This species represents the first branch-off within the clade comprised of monophyletic I. lugens and I. rivulorum subclades, as well as another tentative new taxon obtained in this study (clade designated as "Isoperla PL" with representatives CROPL214-21 and CROPL230-21). The designation "PL" denotes the abbreviation Plitvice Lakes, nearby where a specimen was found. Five sequences of "Isoperla PL" represent 2 haplotypes (CROPL214-21 and CROPL230-21) with low intraspecific uncorrected $p$-distance (0.0096). 


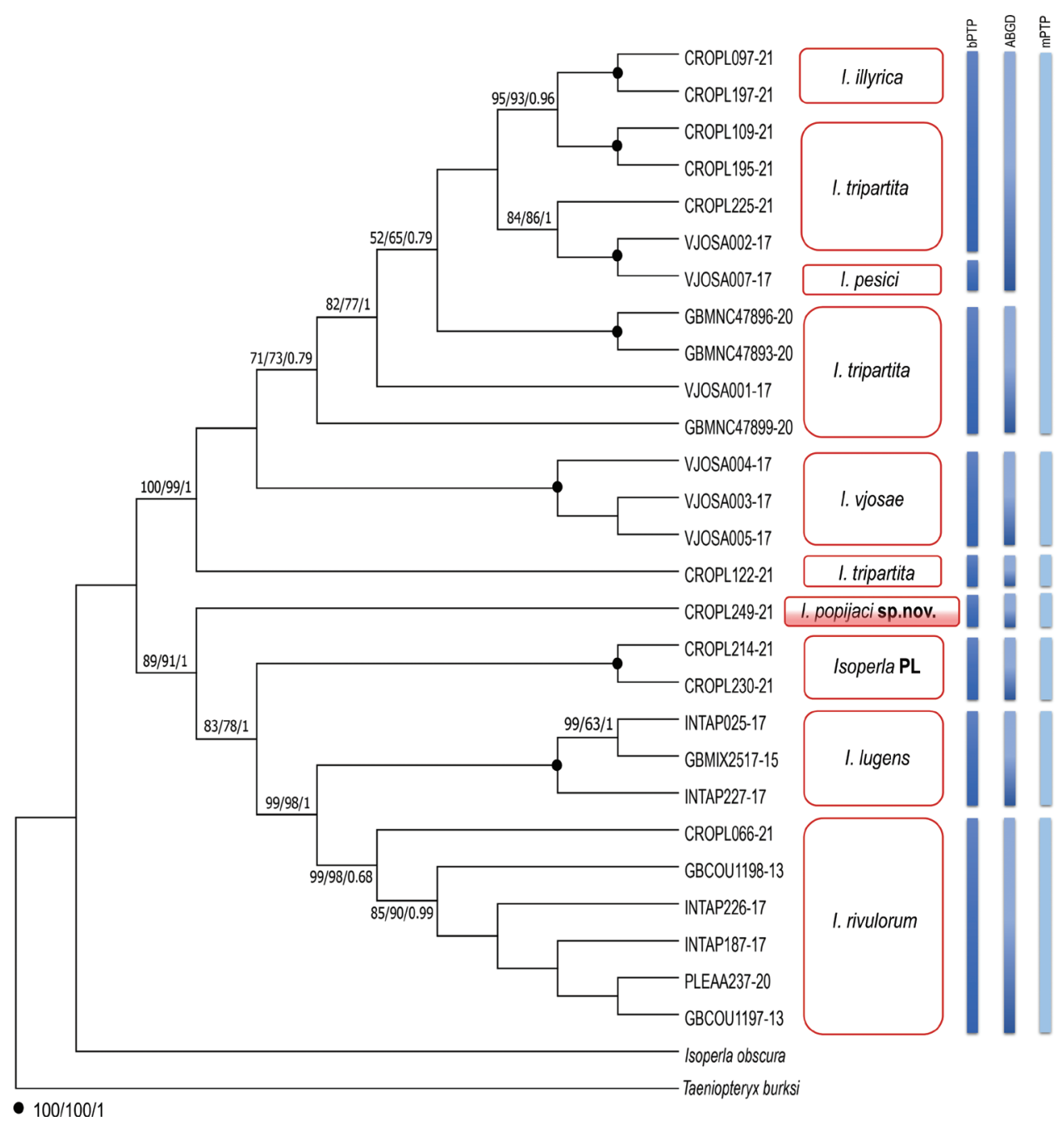

Figure 6. Maximum Likelihood cladogram, based on the analysis of the COI haplotypes of Isoperla species. Numbers at the nodes indicate Neighbour-Joining (NJ), Maximum Likelihood (ML) bootstrap support values (BS) and Bayesian posterior probabilities (BPP), respectively. The results of species delimitations are represented with the vertical bars, from left to right, indicate the OTUs inferred by bPTP, ABGD and mPTP. "Isoperla PL" indicates additional separate lineage obtained in this study. Terminal codes present BOLD/GenBank Process ID, as in Table 1.

Intraspecific uncorrected $p$-distances are as follows for the following species: 0.32 $1.59 \%$ in I. rivulorum, $0.16-0.48 \%$ in I. lugens, $0.01-7.82 \%$ in I. tripartita, $0.32 \%$ in I. vjosae and $0.16 \%$ in I. illyrica. Interspecific uncorrected p-distances for I. popijaci sp. nov. ranged from $6.69-12.59 \%$; specifically, $6.69-7.17 \%$ to I. rivulorum, $8.15-8.45 \%$ to I. lugens, $9.99-10.22 \%$ to I. vjosae, $10.4-12.6 \%$ to I. tripartita, $10.38-12.61 \%$ to I. illyrica, $10.69 \%$ to I. pesici and $8.12 \%$ to the "Isoperla PL" (Figure 7). Overall, observed intraspecific genetic distances within the genus ranged from $0.01-7.82 \%$. 
Within the I. rivulorum clade, Croatian sample CROPL066-21 appeared as a separate lineage, subdivided from Alpine specimens (Figure 6). The uncorrected $p$-distances for sample CROPL066-21 are in the range 1.28-1.59\% to other I. rivulorum samples.

A well-supported clade comprised two newly-discovered lineages (Isoperla popijaci sp. nov. and "Isoperla PL"), together with I. lugens and I. rivulorum, and was recovered in all three tree-building algorithms.

According to the results of the first molecular characterisation of I. illyrica obtained in this study, specimens clustered in a within the monophyletic clade with intraspecific uncorrected $p$-distances of $0.16 \%$. Interspecific $p$-distances between $I$. illyrica and $I$. tripartita ranged from $0.96-5.91 \%$.

All species delimitation analyses (bPTP, ABGD and mPTP) for mtDNA (COI) have delineated two well-separated lineages Isoperla popijaci sp. nov. and "Isoperla PL" as tentative species. Applied methods resulted in various numbers of delineated groups. In the ABGD analysis, initial partitioning identified eight, while recursive partitioning showed the existence of nine putative species for the majority of prior intraspecific divergence values $(\mathrm{P})$. The mPTP method delimited seven operational taxonomic units (OTUs) and, according to these results, is the most conservative approach, while the bPTP recognised 9 OTUs.

Contrary to ABGD and bPTP, the mPTP analysis shows I. illyrica, I. tripartita and $I$. pesici, morphologically assigned to $I$. (tripartita) species group, as a single OTU. These species are completely separated into three OTUs in the bPTP analysis. The separation of sample CROPL122-21 as a distinct species (I. tripartita) was supported by all three species delimitation methods.
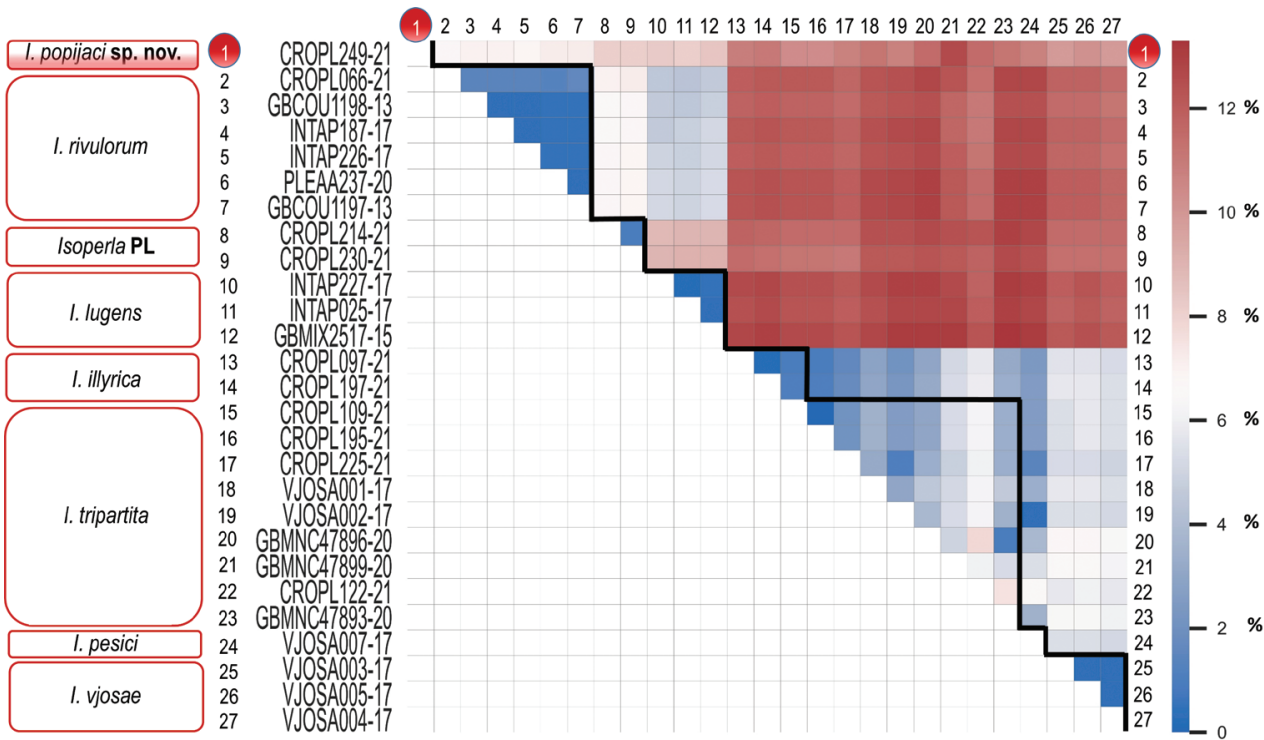

Figure 7. Colour heat map showing inter- and intraspecific uncorrected $p$-distances of the mitochondrial cytochrome oxidase subunit I (COI) barcode region. Isoperla popijaci sp. nov. and Isoperla PL appear as highly divergent. Intraspecific $p$-distances are outlined by the black line. 


\section{Discussion}

\section{Phylogeny and genetic diversity}

The lowest interspecific $p$-distance between $I$. popijaci sp. nov. and I. rivulorum was found to be $6.69 \%$, indicating distinct species. This exceeds intraspecific divergences (ISD $\geq 2 \%$ ) commonly used as one of the criteria for a delimitation of closely-related species in aquatic insects: Ephemeroptera, Plecoptera and Trichoptera (Ball et al. 2009; Zhou et al. 2009). Values above $2 \%$ have already been reported amongst Plecoptera (Zhou et al. 2010, Gill et al. 2015), which was probably caused by poor mobility of some Plecoptera species (Boumans and Baumann 2012) and, consequently, geographical isolation among populations.

The finding of the second well-separated lineage ("Isoperla PL"), most closely related to species I. rivulorum (interspecific $p$-distance from 6.54-7.19\%) implies existence of another new species of the genus Isoperla (unpublished data). Taxa obtained in this study (Isoperla popijaci sp. nov. and "Isoperla PL") are separated by a large interspecific $p$-distance of $8.12 \%$. Future research will seek to determine whether this value has repercussions to the geographical isolation and specificity of the (micro-) habitats in which the taxa were found.

Based on the occurrence of I. lugens (alpine species) and I. rivulorum (alpine, central European species) in the Dinaric karst and their appearance as the most recently diverged lineages within I. popijaci + "Isoperla PL" + I. lugens + I. rivulorum clade (Figure 6), it can be assumed that the Dinaric karst might represent the area of origin of those alpine species as well as the diversification centre from where they spread northwards. However, to test this hypothesis, data across the whole distributional range and use of other molecular markers (mitochondrial and nuclear as well) are necessary.

To establish a final phylogenetic relationship in the monophyletic I. tripartita species group, it is necessary to collect specimens from its entire range and use a multigene molecular approach as well.

Previous research showed the wide range of variability in intraspecific divergence within the order Plecoptera (Zhou et al. 2009; Gill et al. 2015; Stark et al. 2015) and uncorrected intraspecific $p$-distances from our study $(0.01-7.82 \%)$ are consistent with the previously reported values.

\section{Systematic implications}

Based on the morphological characteristics, the new species can be assigned to the Isoperla tripartita species group. The I. tripartita species group is characterised by the divided medial penial armature (into upper and lower coloured portions, divided or subdivided) and lateral penial armatures (Illies 1954; Murányi 2011; Murányi et al. 2016). Popijačs Yellow Sally is characterised by divided medial penial armature, with the distal part bearing short spines, but with indistinct lateral penial armature. The genetic distinction, in combination with morphological features, is significantly different from all other species and promotes I. popijaci sp. nov. as a new species. 
Phylogenetic reconstructions support the monophyly of the $I$. tripartita species group, which is, together with I. grammatica, notable by the high morphological variability of certain species (Zwick 1978; Murányi 2011). In Croatia, significant morphological variability has been also observed in I. inermis from different localities (personal observation), of which some are very similar to I. difformis (Central European species) in the penial armature. Therefore, future studies should investigate relationships between and within Isoperla populations from the Balkan Peninsula (e.g. Cetina River, National Park Plitvice Lakes, Kupa River and nearby springs in Slovenia) by applying a multi-gene approach.

Other species are somewhat less variable and occupy smaller distributional areas (as recently described species from Europe and Asia). Those endemics are of special interest to our study because it is assumed that more endemics species are likely to be discovered, especially in poorly-explored areas with high biodiversity like the Balkans. More new species are expected to be found in Croatia, as the majority of the country's territory has not been studied yet regarding Plecoptera.

Anthropogenic activities have already resulted in the reduction of population size (especially larger species from the genera Perla, Dinocras and Perlodes) (personal observation). All the above-mentioned calls for more detailed studies of species distributional patterns, as well as of genetic diversity of populations. Emphasis should also be put on the isolated habitats (karst areas) as they can have the highest conservation value as refugium and the maintenance of genetic diversity.

\section{Cave-dependent stoneflies?}

Until now, Popijač's Yellow Sally is known to inhabit the parts of the rivulet close to two karstic sources, of which one is a cave entrance. Although there are no true troglobionts within the order Plecoptera, several species have been found to inhabit stream sources around the openings of caves (for example I. inermis) and there are no records of these species from the downstream part of the same stream. Another example is Brachyptera tristis (Klapálek, 1901), a species that spends its entire life cycle underground (the stream of Krupa River) (personal observations). It is, hence, important to pay special attention to the research of caves, pits, underground and temporary rivers and streams that abound in the Dinaric karst geology. These habitats host some of the most complex and diverse faunas (Culver and Sket 2000) as a consequence of composite geological history and the intensive process of karstification (Sket 1999). The Balkan Peninsula is known for its high biodiversity (Sket et al. 2004), especially of aquatic species (Kryštufek et al. 2007, Previšić et al. 2009, 2014; Murányi 2011; Vitecek et al. 2015; Kučinić et al. 2017). It can be expected that future research will contribute to the discovery of biodiversity patterns as well as new species, especially microendemic species (Graf et al. 2009, 2012; Kučinić et al. 2013; Vitecek et al. 2017). Karst habitats, such as Ševerova Cave, represent some of the most dynamic freshwater habitats, especially in terms of biological-geological interactions (Ridl et al. 2018). With the alternation of wet and dry phases and temporal dynamics of water flow, temporary 
rivers have a great influence on local ecological interactions, both in aquatic and terrestrial habitats (Larned et al. 2010). It is a significant assumption that climate change will increase the duration and frequency of dry phases, so it is expected that this will lead to the disappearance of taxa whose entire life cycle (or at least part of it) is related to aquatic environments (Larned et al. 2010).

\section{Conclusions}

Isoperla popijaci sp. nov. is probably a stenoendemic Yellow Sally species found at two karstic sources of the intermittent Krasulja rivulet in Lika (Croatia), which has morphological characteristics similar to species from the I. tripartita species group. Phylogenetic analysis revealed the well-supported sister-group relationship of I. lugens and $I$. rivulorum and a basal position of I. popijaci sp. nov. relative to this clade. Considering its restricted distribution, Isoperla popijaci sp. nov. should have the highest priority in conservation efforts.

\section{Acknowledgements}

The authors would like to acknowledge the financial support from the Croatian Science Foundation (project DNA barcoding of Croatian faunal biodiversity, IP-201606-9988) and Dora Hlebec through ESF (DOK-2018-09-1417). Many thanks to Dr Nikola Tvrtković for assistance, help and support during the fieldwork; to Dr Martina Pavlek, from Ruđer Bošković Institute, Laboratory for Structure and Function of Heterochromatin, for help with the photographic equipment; as well to Professional associate Marijan Marciuš, from Ruđer Bošković Institute, Laboratory for Synthesis of New Materials, for technical support in using scanning electron microscope. Also we are grateful to the Professor Wolfram Graf for his valuable comments and suggestions.

\section{References}

Aubert J (1964) Quelques Plécoptères du Muséum d'Histoire naturelle de Vienne. Annalen des Naturhistorischen Museums Wien 67: 287-301.

Bálint M, Domisch S, Engelhardt CHM, Haase P, Lehrian S, Sauer J, Theissinger K, Pauls SU, Nowak C (2011) Cryptic biodiversity loss linked to global climate change. Nature Climate Change 1: 313-318. https://doi.org/10.1038/nclimate1191

Ball SL, Hebert PDN, Burian SK, Webb JM (2009) Biological identifications of mayflies (Ephemeroptera) using DNA barcodes. Journal of the North American Benthological Society 24(3): 508-524. https://doi.org/10.1899/04-142.1

Boumans L, Baumann RW (2012) Amphinemura palmeni is a valid Holarctic stonefly species (Plecoptera: Nemouridae). Zootaxa 3537(1): 59-75. https://doi.org/10.11646/zootaxa.3537.1.5 
Cao Z, Wang Y, Li W (2020) A new species of Isoperla (Plecoptera: Perlodidae) from China. Zootaxa 4858(2): 251-260. https://doi.org/10.11646/zootaxa.4858.2.6

Chen ZT, Song LD, Feng WT (2019) A new species of Isoperla (Plecoptera: Perlodidae) from the Qinling Mountains of northwestern China and notes on the Chinese species of the genus. Zootaxa 4651(2): 379-391. https://doi.org/10.11646/zootaxa.4651.2.11

Culver DC, Sket B (2000) Hotspots of subterranean biodiversity in caves and wells. Journal of Cave and Karst Studies 62(1): 11-17.

Darriba D, Taboada GL, Doallo R, Posada D (2012) jModelTest 2: more models, new heuristics and parallel computing. Nature Methods 9(8): 772. https://doi.org/10.1038/nmeth.2109

Despax R (1936) Contribution à l'étude du genre Chloroperla (Pictet) (Isoperla Banks). Bulletin de la Societe d'Histoire Naturelle de Toulouse 69: 337-398.

DeWalt RE, Maehr MD, Hopkins H, Neu-Becker U, Stueber G (2020) Plecoptera Species File Online. Version 5.0/5.0. http://Plecoptera.SpeciesFile.org [Accessed 12 December 2020]

DeWalt RE, Ower GD (2019) Ecosystem services, global diversity, and rate of Stonefly Species descriptions (Insecta: Plecoptera). Insects 10(4): 99. https://doi.org/10.3390/insects10040099

Ferreira S, Tierno de Figueroa JM, Martins FMS, Verissimo J, Quaglietta L, Grosso-Silva JM, Lopes PB, Sousa P, Paupério J, Fonseca NA, Beja P (2020) The InBIO Barcoding Initiative Database: contribution to the knowledge on DNA barcodes of Iberian Plecoptera. Biodiversity Data Journal 8: e55137 https://doi.org/10.3897/BDJ.8.e55137

Fochetti R, Tierno de Figueroa JM (2008) Global diversity of stoneflies (Plecoptera; Insecta) in freshwater. Hydrobiologia 595: 365-377. https://doi.org/10.1007/s10750-007-9031-3

Folmer O, Black M, Hoeh W, Lutz R, Vrijenhoek R (1994) DNA primers for amplification of mitochondrial cytochrome c oxidase subunit I from diverse metazoan invertebrates. Molecular Marine Biology and Biotechnology 3: 294-299.

Gill BA, Sandberg JB, Kondratieff BC (2015) Evaluation of the morphological species concepts of 16 western Nearctic Isoperla species (Plecoptera: Perlodidae) and their respective species groups using DNA barcoding. Illiesia 11(11): 130-146.

Graf W, Pauls SU, Vitecek S (2018) Isoperla vjosae sp. nov., a new species of the Isoperla tripartita group from Albania (Plecoptera: Perlodidae). Zootaxa 4370(2): 171-179. https://doi. org/10.11646/zootaxa.4370.2.5

Graf W, Konar M, Murányi D, Orci K, Vitecek S (2014) A new species of Isoperla (Insecta, Plecoptera) from the Karawanken, with considerations on the Southern Limestone Alps as centers of endemism. ZooKeys 448: 27-36. https://doi.org/10.3897/zookeys.448.8509

Graf W, Popijač A, Previšić A, Gamboa M, Kučinić M (2012) Contribution to the knowledge of Siphonoperla in Europe (Plecoptera: Chloroperlidae): Siphonoperla korab sp. nov. Zootaxa 3164(1): 41-48. https://doi.org/10.11646/zootaxa.3164.1.4

Graf W, Lorenz AW, Tierno de Figueroa JM, Lücke S, López-Rodríguez MJ, Davies C (2009) Distribution and Ecological Preferences of European Freshwater Organisms. Volume 2 - Plecoptera. In: Schmidt-Kloiber A, Hering D (Eds) Distribution and ecological preferences of European freshwater organisms. Pensoft Publishers, Sofia-Moscow, 262pp.

Hamid SA, Rawi CS (2017) Application of Aquatic Insects (Ephemeroptera, Plecoptera and Trichoptera) in water quality assessment of Malaysian Headwater. Tropical Life Sciences Research 28(2): 143-162. http://doi.org/10.21315/tlsr2017.28.2.11 
Hajibabaei M, Janzen DH, Burns JM, Hallwachs W, Hebert PDN (2006) DNA barcodes distinguish species of tropical Lepidoptera. Proceedings of the National Academy of Sciences of the USA 103(4): 968-971. https://doi.org/10.1073/pnas.0510466103

Hebert PDN, Stoeckle MY, Zemlak TS, Francis CM (2004) Identification of Birds through DNA Barcodes. PLOS BIOLOGY 2(10): e312. https://doi.org/10.1371/journal. pbio.0020312

Illies J (1952) Die europäischen Arten der Plecopterengattung Isoperla Banks (= Chloroperla Pictet). Beiträge zur Entomologie 2(4-5): 369-424. https://doi.org/10.21248/contrib.entomol.2.4-5.369-424

Illies J (1954) Isoperla tripartita n. sp., eine neue Plecoptere aus dem Wienerwald. Österreichische Zoologische Zeitschrift 5: 118-122.

Illies J (1966) Katalog der rezenten Plecoptera. Das Tierreich, Berlin 82: 1-632.

Illies J, Schmitz W (1980) Die Verfahren der biologischen Beurteilung des Gewässerzustandes der Fließgewässer (systematisch-kritische Übersicht). Studien zum Gewässerschutz 5, Karlsruhe, 125 pp.

IUCN (2001) IUCN Red List Categories and Criteria: Version 3.1. IUCN Species Survival Commission. IUCN, Gland, Switzerland and Cambridge, UK: 30 pp.

Ji X-Y, Du Y-Z, Wang, Z-J (2014) Two new species of the stonefly genus Amphinemura (Insecta, Plecoptera, Nemouridae) from China. ZooKeys 404: 23-30. https://doi.org/10.3897/ zookeys.404.7067

Kaćanski D, Zwick P (1970) Neue und wenig bekannte Plecopteren aus Jugoslawien. Mitteilungen der Schweizerischen Entomologischen Gesellschaft 43(1): 1-16.

Kapli P, Lutteropp S, Zhang J, Kobert K, Pavlidis P, Stamatakis A, Flouri T (2017) Multi- rate Poisson tree processes for single-locus species delimitation under maximum likelihood and Markov chain Monte Carlo. Bioinformatics 33(11): 1630-1638. https://doi.org/10.1093/ bioinformatics/btx025

Klapálek F, Grünberg K (1909) Ephemerida, Plecoptera, Lepidoptera. Süsswasserfauna Deutschlands: 8 .

Klapálek F (1923) Plécoptères nouveaux. Annales de la Société Entomologique de Belgique 63: 21-29.

Katoh K, Standley DM (2013) MAFFT Multiple Sequence Alignment Software Version 7: improvements in performance and usability. Molecular Biology and Evolution 30(4): 772 780. https://doi.org/10.1093/molbev/mst010

Kryštufek B, Bužan EV, Hutchinson WF, Hänfling B (2007) Phylogeography of the rare Balkan endemic Marti-no's vole, Dinaromys bogdanovi, reveals strong differentiation within the western Balkan Peninsula. Molecular Ecology 16(6): 1221-1232. https://doi.org/10.1111/ j.1365294X.2007.03235.x

Kučinić M, Szivák I, Pauls SU, Bálint M, Delić A, Vučković I (2013) Chaetopteryx bucari sp. nov., a new species from the Chaetopteryx rugulosa group from Croatia (Insecta, Trichoptera, Limnephilidae) with molecular, taxonomic and ecological notes on the group. ZooKeys 320: 1-28. https://doi.org/10.3897/zookeys.320.4565

Kučinić M, Previšić A, Vajdić M, Tunjić M, Mihoci I, Žalac S, Sviben S, Vučković I, Trupković M, Habdija I (2017) First systematic investigation of adults and second checklist of caddis- 
flies of the Plitvice Lakes National Park with notes on research history, biodiversity, distribution and ecology. Natura Croatica, 26: 225-260. https://doi.org/10.20302/NC.2017.26.19 Kumar S, Stecher G, Li M, Knyaz C, Tamura K (2018) MEGA X: Molecular Evolutionary Genetics Analysis across computing platforms. Molecular Biology and Evolution 35(6): 1547-1549. https://doi.org/10.1093/molbev/msy096

Larned ST, Datry T, Arscott DB, Tockner K (2010) Emerging concepts in temporary-river ecology. Freshwater Biology 55(4): 717-738. https://doi.org/10.1111/j.1365-2427.2009.02322.x

Letunic I, Bork P (2021) Interactive Tree Of Life (iTOL) v4: recent updates and new developments. Nucleic Acids Research 47(W1): W256-W259. https://doi.org/10.1093/nar/gkz239 Li WH, Yao G, Qin XF (2013) Haploperla choui sp. nov. (Plecoptera: Chloroperlidae), a remarkable new stonefly from Qinling Mountains of China. Zootaxa 3640 (4): 550- 556. https://doi.org/10.11646/zootaxa.3640.4.3

Li W, Murányi D (2015) A remarkable new genus of Perlodinae (Plecoptera: Perlodidae) from China, with remarks on the Asian distribution of Perlodinae and questions about its tribal concept. Zoologischer Anzeiger 259: 41-53. https://doi.org/10.1016/j.jcz.2015.10.003

Malinar H, Čepelak M (2009) Špilje u hidrogeološkom sustavu Krbavica - Krbavsko polje. Speleolog 56: 20-38.

Michalik A, Miliša M, Michalik K, Rościszewska E (2017) The structure and ultrastructure of the egg capsules of stoneflies of the genus Isoperla (Insecta, Plecoptera, Perlodidae). Microscopy Research and Technique 80(11): 1-13. https://doi.org/10.1002/jemt.22922

Morinière J, Hendrich L, Balke M, Beermann AJ, König T, Hess M, Koch S, Müller R, Leese F, Hebert PDN, Hausmann A, Schubart CD, Haszprunar G (2017) A DNA barcode library for Germany's mayflies, stoneflies and caddisflies (Ephemeroptera, Plecoptera and Trichoptera). Molecular Ecology Resources 17(6): 1293-1307. https://doi.org/10.1111/1755-0998.12683 Murányi D (2011) Balkanian species of the genus Isoperla Banks, 1906 (Plecoptera: Perlodidae). Zootaxa 3049: 1-46. https://doi.org/10.11646/zootaxa.3049.1.1 Murányi D, Kovács T, Orci KM (2016) Contribution to the taxonomy and biology of two Balkan endemic Isoperla Banks, 1906 (Plecoptera: Perlodidae) species. Zoosymposia 11: 73-88. https://doi.org/10.11646/zoosymposia.11.1.11

Murányi D, Kovács T, Graf W (2020) A new species of Isoperla (Plecoptera: Perlodidae) from the Southern Carpathians, and further contributions to the fauna of the T3arcu Mts. Acta Phytopathologica et Entomologica Hungarica 55 (2): 235-248. https://doi. org/10.1556/038.55.2020.025

Pictet FJ (1841) Histoire naturelle générale et particulière des insectes névroptères 1(1): e284 https://doi.org/10.5962/bhl.title.124172

Poda von Neuhaus N (1761) Insecta Musei Graecensis, quae in ordines, genera et species juxta Systema Naturae Linnaei digessit. Graecii, Widmanstad 1-127.

Popijač A, Sivec I (2009a) First records of the alpine stonefly species Protonemura julia Nicolai, 1983 (Insecta, Plecoptera) in Croatia. Natura Croatica 18(1): 83-89.

Popijač A, Sivec I (2009b) Stoneflies (Insecta, Plecoptera) from museum collections in Croatia. Natura Croatica 18(2): 243-254. 
Previšić A, Walton C, Kučinić M, Mitrikeski PT, M Kerovec (2009) Pleistocene divergence of Dinaric Drusus endemics (Trichoptera, Limnephilidae) in multiple microrefugia within the Balkan Peninsula. Molecular Ecology 18: 634-647. https://doi.org/10.1111/j.1365-294X.2008.04046.x

Previšić A, Schnitzler J, Kučinić M, Graf W, Ibrahimi H, Kerovec M, Pauls SU (2014) Microscale vicariance and diversification of Western Balkan caddisflies linked to karstification. Freshwater Science 33(1): 250-262. https://doi.org/10.1086/674430

Puillandre N, Lambert A, Brouillet S, Achaz G (2012) ABGD, Automatic Barcode Gap Discovery for primary species delimitation. Molecular Ecology 21: 1864-1877. https://doi. org/10.1111/j.1365-294X.2011.05239.x

Rambaut A. (2009) FigTree v1.4.3. (Computer Program). Available at http://tree.bio.ed.ac.uk/ [Accessed 9 February 2021]

Rambaut A, Drummond AJ, Xie D, Baele G, Suchard MA (2018) Posterior summarisation in Bayesian phylogenetics using Tracer 1.7. Systematic Biology 67(5): 901-904. https://doi. org/10.1093/sysbio/syy032.

Ratnasingham S, Hebert PDN (2007) bold: The Barcode of Life Data System (http://www.barcodinglife.org). Molecular Ecology Notes 7(3): 355-364. https://doi.org/10.1111/j.14718286.2007.01678.x

Ridl A, Vilenica M, Ivković M, Popijač A, Sivec I, Miliša M, Mihaljević Z (2018) Environmental drivers influencing stonefly assemblages along a longitudinal gradient in karst lotic habitats. Journal of Limnology 77(3): 412-427. https://doi.org/10.4081/jlimnol.2018.1816

Ronquist F, Teslenko M, van der Mark P, Ayres DL, Darling A, Höhna S, Larget B, Liu L, Suchard MA, Huelsenbeck JP (2012) MRBAYES 3.2: Efficient Bayesian phylogenetic inference and model selection across a large model space. Systematic Biology 61: 539-542. https://doi.org/10.1093/sysbio/sys029

Sandberg JB, Kondratieff BC (2013) The Isoperla of California (Plecoptera: Perlodidae); Updated male descriptions and adult keys for 18 western Nearctic species. Illiesia 9: 34-64.

Sket B (1999) High biodiversity in hypogean waters and its endangerment - The situation in Slovenia, the Dinaric Karst, and Europe. Crustaceana 72(8): 767-779. https://doi. org/10.1163/156854099503951

Sket B, Paragamian K, Trontelj P (2004) A Census of the Obligate Subterranean Fauna of the Balkan Peninsula. In: Griffiths HI, Kryštufek B, Reed JM (Eds) Balkan Biodiversity: Pattern and Process in the European Hotspot. Kluwer Academic Publishers, Dordrecht. 309-322. https://doi.org/10.1007/978-1-4020-2854-0_18

South EJ, Skinner RK, DeWalt RE, Kondratieff BC, Johnson KP, Davis MA, Lee JJ, Durfee RS (2020) Phylogenomics of the North American Plecoptera. Systematic Entomology 46(1): 287-305. https://doi.org/10.1111/syen.12462

Szczytko SW, Stewart KW (1979) The genus Isoperla (Plecoptera) of western North America; holomorphology and systematics and a new stonefly genus Cascadoperla. Memoirs of the American Entomological Society 32: 1-120.

Szczytko SW, Kondratieff BC (2015) A review of the eastern Nearctic Isoperlinae (Plecoptera: Perlodidae) with the description of twenty-two new species. Monographs of Illiesia 1: 1-289. 
Sivec I, Stark BP (2002) The species of Perla (Plecoptera: Perlidae): evidence from egg morphology. Scopolia 49: 1-33.

Stark BP, Kondratieff B, Sandberg J, Gill B, Verdone C, Harrison A (2015) Sierraperla Jewett, 1954 (Plecoptera: Peltoperlidae), distribution, egg morphology and description of a new species. Illiesia 11(2): 8-22.

Tabacaru J (1971) Une nouvelle espèce du genre Isoperla (Plecoptera, Perlodidae) de Yougoslavie. Fragmenta Balcanica Musei Macedonici Scientiarum Naturalium 8(2): 9-15.

Urbanič G, Toman MJ (2007) Influence of environmental variables on Stream Caddis Larvae in three Slovenian Ecoregions: Alps, Dinaric Western Balkans and Pannonian Lowland. International Review of Hydrobiology 92(4-5): 582-602. https://doi.org/10.1002/ iroh.200510995

Vitecek S, Kučinić M, Oláh J, Previšić A, Bálint M, Keresztes L, Waringer J, Pauls SU, Graf W (2015) Description of two new filtering carnivore Drusus species (Limnephilidae, Drusinae) from the Western Balkans. ZooKeys 513: 79-104. https://doi.org/10.3897/zookeys.513.9908

Vitecek S, Kučinić M, Previšić A, Živić I, Stojanović K, Keresztes L, Bálint M, Hoppeler F, Waringer J, Graf W, Pauls SU (2017) Integrative taxonomy by molecular species delimitation: multi-locus data corroborate a new species of Balkan Drusinae microendemics. BMC Evolutionary Biology 17: 1-129 https://doi.org/10.1186/s12862-017-0972-5

Villesen P (2007) FaBox: an online toolbox for fasta sequences. Molecular Ecology Notes 7: 965-968. https://doi.org/10.1111/j.1471-8286.2007.01821.x

Waskom M (2021) Seaborn: statistical data visualization. Journal of Open Source Software 6(60) 3021. https://doi.org/10.21105/joss.03021

Zhang J, Kapli P, Pavlidis P, Stamatakis A (2013) A general species delimitation method with applications to phylogenetic placements. Bioinformatics 29: 2869-2876. https://doi. org/10.1093/bioinformatics/btt499

Zhou X, Adamowicz SJ, Jacobus LM, DeWalt RE, Hebert PDN (2009) Towards a comprehensive barcode library for Arctic life - Ephemeroptera, Plecoptera, and Trichoptera of Churchill, Manitoba, Canada. Frontiers in Zoology 6(30): 1-9. https://doi. org/10.1186/17429994-6-30

Zhou X, Jacobus LM, DeWalt RE, Adamowicz SJ, Hebert PDN (2010) Ephemeroptera, Plecoptera, and Trichoptera fauna of Churchill (Manitoba, Canada): Insights into biodiversity patterns from DNA barcoding. Journal of the North American Benthological Society 29(3): 814-837. https://doi.org/10.1899/09-121.1

Zwick P (1973) Insecta: Plecoptera. Phylogenetisches System und Katalog. Das Tierreich, W. de Gruyter, Berlin, 1-465.

Zwick P (1978) Steinfliegen (Plecoptera) aus Griechenland und benachbarten Ländern - 2. Teil. Mitteilungen der Schweizerischen Entomologischen Gesellschaft 51: 213-239.

Zwick P (2004) Key to the West Palaearctic genera of stoneflies (Plecoptera) in the larval stage. Limnologica 34(4): 315-348. https://doi.org/10.1016/S0075-9511(04)80004-5 